\title{
Mobile Game Developing: Math Mobile Game Learning Model
}

\author{
Hadi Sutopo
}

\begin{abstract}
This research is intended to develop a mobile multimedia application, specially a mathematics mobile game model for elementary school. This learning model should encourage student's ability to learn mathematics particularly numbers. This research consists of 7 steps such as research and information collecting, planning, developing preliminary product, preliminary field testing, preliminary product revision, main field testing, and operational product revision. Subjects of the research are education, visual communication and computer experts in preliminary field testing, and the elementary school children for implementation revised model in main field testing. The data were analyzed using the analytic descriptive method and interpreted based on the narrative way as research findings. Based on the data of product and learning process taken in the main field testing, most of children could solve the problem on mathematics mobile game, the mathematics mobile game was very useful to support learning, motivate children to learn mathematics, and it could be used for self-learning.
\end{abstract}

Index Terms-Mathematics, multimedia, mobile game, ActionScript.

\section{INTRODUCTION}

Learning is a necessity in life, since his/her birth till the ends. As a human, we learn to be able to achieve our independence and to adapt to various environmental changes [1]. Mathematics learning at elementary school is poor, formally, and theoretically, and very book-based learning. Because mathematics is a difficult subject for many children to grasp, keeping the fun alive may just be a way to assist children in their quest for knowledge. Children cannot understand mathematics easily, and they assume that mathematics is very hard to learn. Teachers are very tired to explain about mathematics that is not easy to make children understand. Mathematics can be an interesting topic for children if they can learn in a relaxed situation like playing game. Children and mathematics can be a great mix with a little planning and a focus on the fact that children learn through play. These tips for fun mathematics can be used effectively throughout elementary school and even into junior high. The mathematics topic at elementary school are including number, measurement, fractions, geometry, perimeter and area plane figure [2], but it is only simple mathematics as numbers that is included on the game.

Rapid development in ICT (Information Communication Technology) has changed lifestyle today, including in

Manuscript received August 20, 2016; revised March 6, 2017.

Hadi Sutopo is with Faculty of Computer Science and Communication Science, Institut Teknologi dan Bisnis Kalbis, Jakarta, Indonesia (e-mail: hadi.sutopo@kalbis.ac.id). learning method. There are several learning methods that apply ICT such as computer-based learning, e-learning, distance learning, etc. Computer-based learning implementation in the learning process using multimedia increases creativity and innovations. Multimedia is a combination of text, image, sound, animation, and video that is delivered via computer or electronic and digital equipment [3]. Using together multimedia elements such as images and animation that are equipped with sound, video clips, and text, will be able give clear meaning to those who need it. T. Vaughan stated that multimedia can bring radical changes in the learning process, from passive student learning to active student learning. When computers and software are used so that children have new methods of learning curriculum, these tools can promote and enhance children's understanding of content in powerful ways. They can find information, use image and sound as well as text to communicate what they have learned. The explosive growth of mobile devices is stimulating widespread efforts to clone almost any technology developed for desktop computers to mobile devices [4]. Mobile technologies offer the opportunity to embed learning in a natural environment. Mobile devices such as smart phones are becoming widely used on schools, and as the shape of computing is evolving more into a mobile environment.

R. Mayer in C.M. Reigeluth [5] argued that constructivist learning activities are conducted on student's cognitive processes during learning, including selecting relevant information, organizing the information produced, and integrating information with existing knowledge. The theory of constructivist learning focuses on the way that knowledge is constructed by the learner in working memory. In this construction process the learner uses both incoming material from the environment and prior knowledge in long-term memory. He further stressed on three constructivist processes that is called SOI model, namely S (selecting), O (Organizing), and I (Integrating). The SOI model is a theory of learning that can be used to generate instructional implications.

This study aims to develop a multimedia mobile mathematics game, as it is presented in Fig. 1. This learning model can be used by children anywhere. By playing the game on mobile device, it is expected to enhance children in mathematics learning. Mathematics game that runs on mobile device is a simple game, i.e. press Start button to begin the game, and select the options of tutorial, practice, and evaluation. In the practice section, user solves the problem of addition, subtraction, sorting, and grouping. Other research focus on the use of math computer games for the remediation of specific deficits, such as A. Katmada et al. created a research that focused on the design, 
implementation and evaluation of an online game for elementary and middle school mathematics. The aim is two topics, (1) the development of the prototype of a flexible and adaptable computer game; and (2) the evaluation of this prototype, as to its usability and technical aspects. The computer game was created in an attempt to facilitate the teaching of mathematics, a subject that is often regarded as complicated by children of all ages [6].
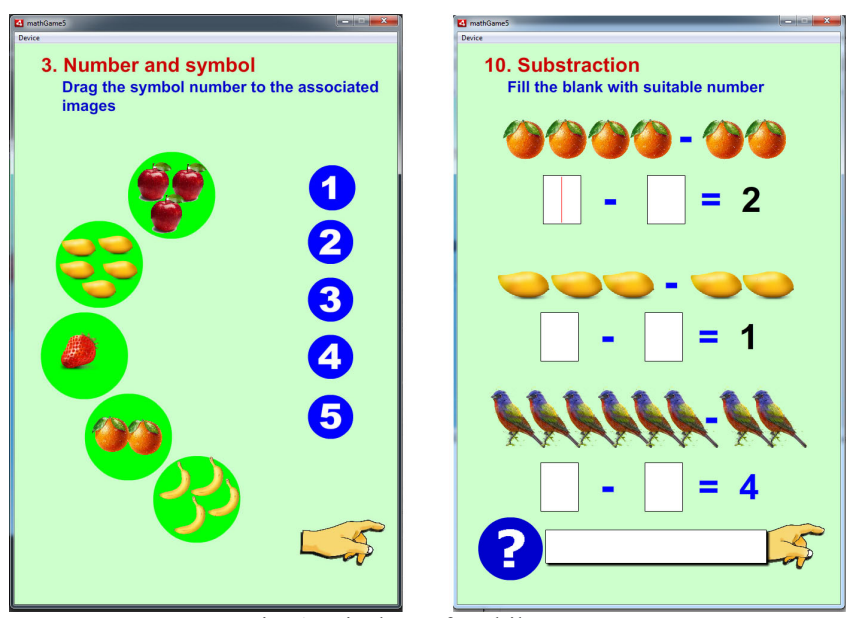

Fig. 1. Displays of mobile game.

\section{METHOD}

This study uses Research and Development (R \& D) according to W.R. Borg and M.D. Gall [7], which consists of ten following stages: (1) Research and Preliminary Information Collecting, (2) Planning, (3) Developing Preliminary Product, (4) Preliminary Testing, (5) Preliminary Product Revision, (6) Main Field Testing, (7) Operational Product Revision that produce mobile game and can be used by children to learn mathematics, (8) Operational Testing, (9) Final Product Revision, and (10) Dissemination and Implementation.

This research, as can be seen in Fig. 2, covers only seven stages, in accordance with the needs of the learning material in elementary school, include: (1) Research and Preliminary Information Collecting. In this phase, the estimation of user identification, objective of mathematics learning, infrastructure of mobile game, and learning and research literature; (2) Planning. After obtaining the necessary information, the next step is to plan the scope of mathematics learning and designing mobile game; (3) Developing Preliminary Product. After the initiation of the comprehensive plan, the main step in the stage is to make an early product of mobile learning game that can be tested. At this stage the necessary feedback and suggestions from colleagues in related fields, namely education, visual communication and information technology; (4) Preliminary Testing. Initial testing of the expert evaluations, conducted after initial product completely developed, are related to education, visual communication, and information technology; (5) Preliminary Product Revision. After the initial testing, the next stage is revising the product in accordance to the evaluation data obtained from the initial testing; (6) Main Field Testing. After the initial product is revised, field testing is conducted for evaluation of the product. The questionnaire used to obtain feedback from children, teachers, and parrents. Interviews were conducted on several of them during the testing stage; and (7) Operational Product Revision. Having conducted main field testing, the next stage is product revision as a mobile game for using by children.

The object is of the research is the mathematics mobile game, and the research location is conducted at the Elementary School "X' in Jakarta, Indonesia. Respondents consist of children who are learning at the first grade of the school. Subject Matter Expert (SME) in education, visual communication, and information technology evaluate the preliminary product.

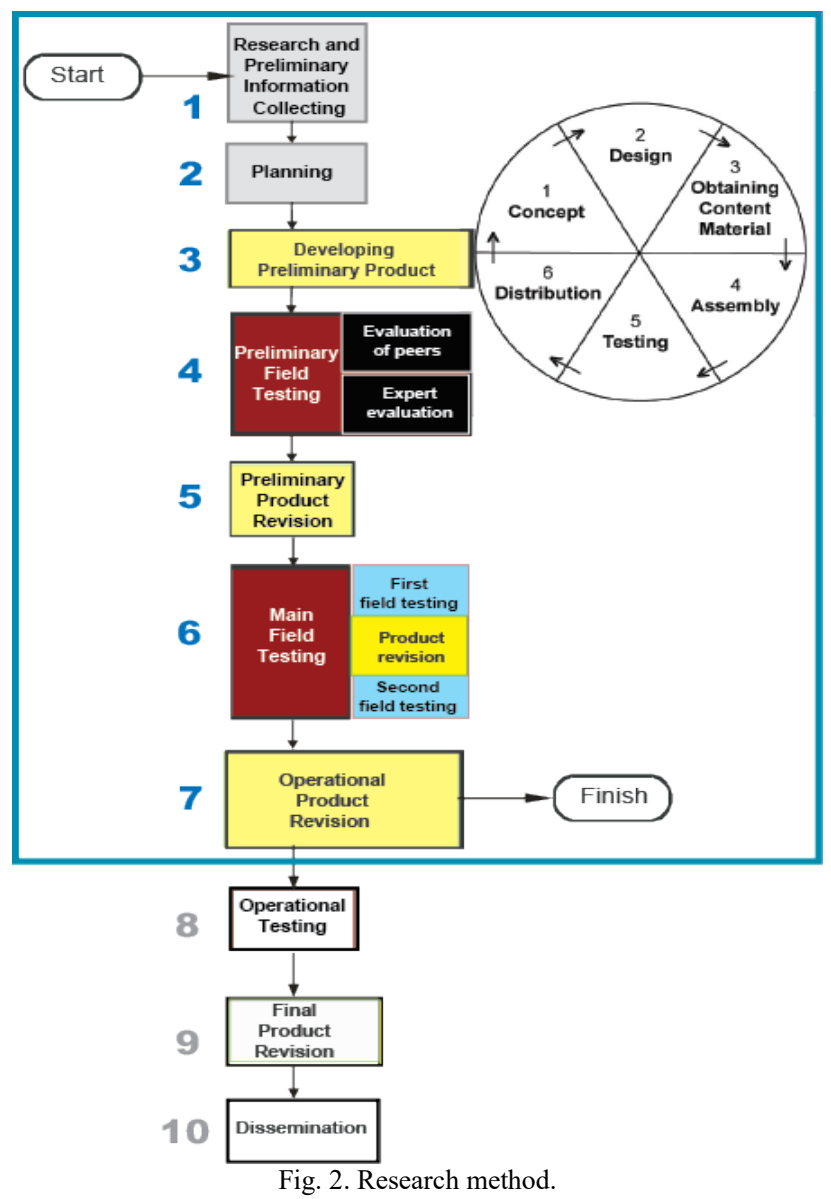

The data is analyzed using the analytical descriptive method and interpreted in a narrative way based on the research findings. Analyzing and data processing carried out with six stages include gathering data, preparing data for analysis, careful reading, developing the code, presenting the data and analyzing the data [8]. The data is collected from questionnaires and interviews with details: (1) Questionnaires are used to find useful information that supports the theory, the information is needed for model development, information on whether a student can perform the command to play the mobile mathematics game, as well as assessing the quality of the learning model that is developed; (2) Interviews with open-ended questions are used, hence respondents can give information that is not limited from different perspective. Depth interviews are necessary to obtain data about the product and the learning process trough play the game; (3) Observations are conducted to obtain data about playing the game and the impact of mathematics learning. Observations require 
thoroughness and attention to listena carefully and obtain the detailed events that are seen.

Procedural model of mobile game product planning is a combination of Borg and Gall research methodology and multimedia development method according Luther that can be seen in Fig. 2. At the third stage of research and development according to Borg and Gall, the process of Develop Preliminary Product uses multimedia development methods based on Luther. Design stage is the stage where the entire multimedia object is planned, and create design including storyboard and the navigation structure.

According to A.C. Luther [9], development of multimedia has six stages: Concept, Design, Material Collecting, Assembly, Testing, and Distribution. In the second stage, Design, is developing a navigation structure and storyboard of application. First, it established lateral thought processes, helping to break down the navigation structure that is usually embedded in traditional approaches to course delivery. Second, it can obtain result in an overview based on quite abstract design, which is in turn generates fresh implementation. Third, it provides a storyboard for identifying relationships between the components, and navigation structure as the essential to design an interactive multimedia application.

\section{RESULT AND DISCUSSION}

\section{A. Research and Preliminary Information Collecting}

The objective of this stage was getting the information that was needed by children, and teacher in playing mathematics mobile game, production equipment and human resources to develop the product. This phase of research carried out on a small scale at Elementary School " $X$ " in Jakarta Indonesia, involving 32 children at first grade and 4 teachers. They stated that mobile game should be provided with many pictures, hence children would be intersested to play, and intearctivity in visualization of mathematics operations. Visualization is presenting a topic that is not easy to be understood usually is used in science, engineering, medical, etc. The data are converted to a visual form that is helpful for the users in analyzing their problem [10].

Equipment that was used to produce mobile mathematics game development was already available, that was a desktop computer with $4 \mathrm{~GB}$ of RAM, $250 \mathrm{~GB}$ hard drive and a mobile phone with Android operating system. The system software was Windows 7 Professional with the authoring tool Adobe Flash Professional CC. Adobe Flash is a visual object-oriented programming tool and can be used to develop interactive multimedia application [11].

Human resources necessary in creating mobile game consisted of author, illustrator, animator, video editor, multimedia programmer and multimedia designer. Based on the information on the research and initial data collection, development of mathematics mobile game should include few items: (1) Categories of font design, history, characteristics and usage, text and background colors in accordance with the theory [12]. Knowledge of graphic design principles is necessary to built the communicative and aesthetic message, (2) Animated mobile game with score, (3) Writing code or programming the way how to input data, mathematics operations, feedback, and scoring, (4) Multimedia objects i.e, symbol of movie clip, a tool of animation and interactive buttons, (5) File format that was piblished are SWF and APK (6) Publishing to Google Play Store in order that mobile game could be download by teachers, children, and parents.

\section{B. Planning}

Designing the tutorial was required, so that the learning process became more effective and efficient. There were several topics in the mathematics mobile game development based on learner's requirement. The topics were conceptual tutorial, practice, and evaluation. The learning material on mathematics in the Tutorial was about numbers with their operations. There were 10 problems of mathematics operations in the Practice about number identification: (1) Introduction to number; (2) Input numbers in order to be sorted; (3) Number and symbol; (4) Sorting; (5) Shape and number; (6) Grouping; (7) Addition; (8) Substraction; (9) Addition - filling blanks; and (10) Substraction - filling blanks. Every topic was provided with images of fruit and animals that could be interested by children. Children's competency was achieved by doing the problems in Evaluation.

The next step is developing a navigation structure and storyboard of the mathematics mobile game reaching the objectives, serves several purposes. The scene 1 is title page that was continued with scene 2 containing tutorial. Scene 3 contained 10 topics and Scene 4 was Evaluation that contained 10 topics. The last Scene 5 was the end of the game which user could see the score he or she gained. At the scene user could either play again nor exit. Fig. 3 shows the navigation structure of the game.

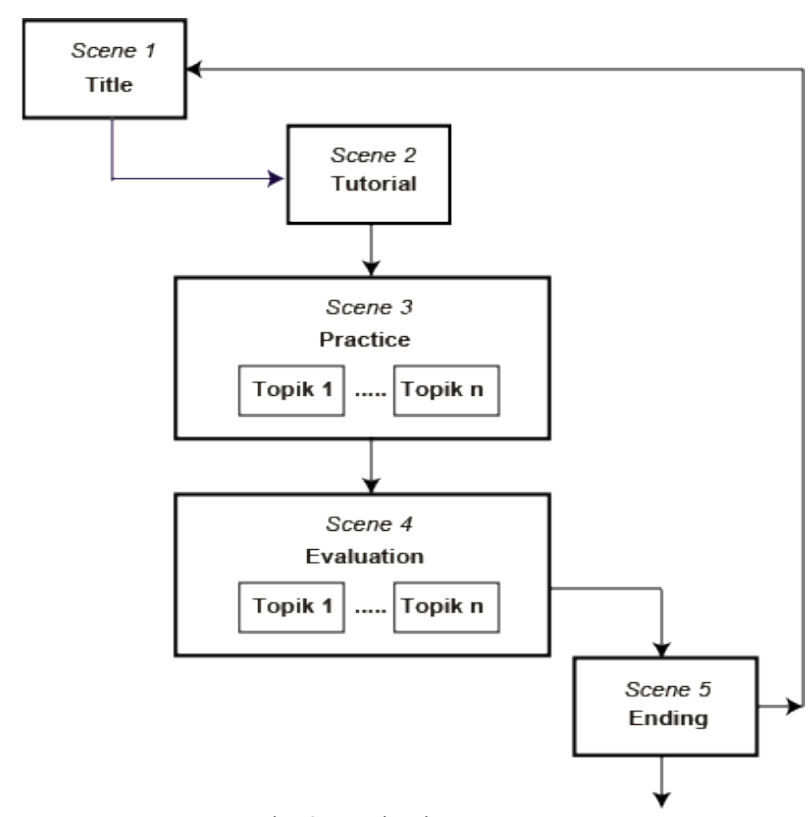

Fig. 3. Navigation structure.

\section{Developing Preliminary Product}

Collecting of materials could be done in parallel with the stages of production. In this stage the materials such as images, animations, audio, video and other products were collected to be used in the next stage. 
Production stage was the stage where the entire multimedia object was created, and making application based on the storyboard and the navigation structure. Because the mobile game had a lot of interactivity and complexity, it was necessary to use ActionScript 3 programming which was the part of the Adobe Flash authoring [13].

Adobe Flash is a multimedia authoring originally acquired by Macromedia and currently developed and distributed by Adobe Systems. Since its introduction in 1996 Flash has become a popular method for adding animation and interactivity to web pages. Flash is commonly used to create animation, advertisements, and various web page Flash components, to integrate video into web pages, and more recently, to develop rich Internet applications [14]. Flash can manipulate vector and raster graphics, and supports bidirectional streaming of audio and video. It contains a scripting language called ActionScript. The Adobe Flash Professional CC was used to create content applications, i.e. games, presentations, content for mobile phones and other embedded devices.

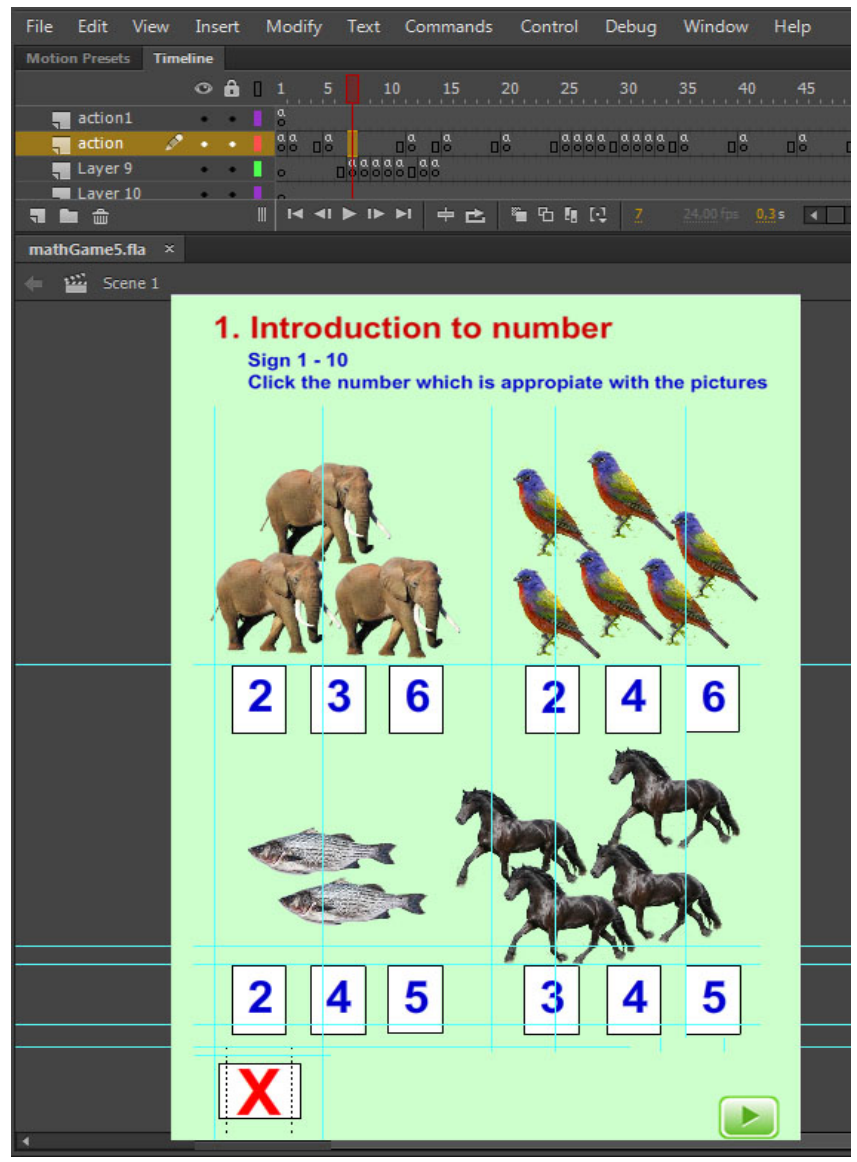

Fig. 4. Stage of flash professional

Developing mathematics mobile game would provide the first exposure to children in the graphical user interface components of a mobile application. It would expose them to commonly used elements such as images, symbol of numbers, sorting, choice groups, etc. They would also gain knowledge in working with user choices and results, and processing the user input to solve mathematics problem with score output. Screen navigation can also be shown to the children so they could learn how to understand the information in a mobile application. To create a game with
Adobe Flash, some activities should be done: (1) Import some images of animals and fruits and place them at the stage; (2) Create some input text fields which can be inputed with number, then put it into the stage; (3) Create a button as interactivity tool; (4) Create an animated title and some graphics with color effects; (5) Make feedback that tells to the player weather he or she succeeds or fails in playing the game; (6) Make scores and calculate them that presens user achievement; (7) Make script on frames that using ActionScript 3 [15]. Fig. 3 shows some of layers to place image, label, text, button, and actions, and Fig. 4 shows a part of ActionScript 3, that presents a function in calculating score.

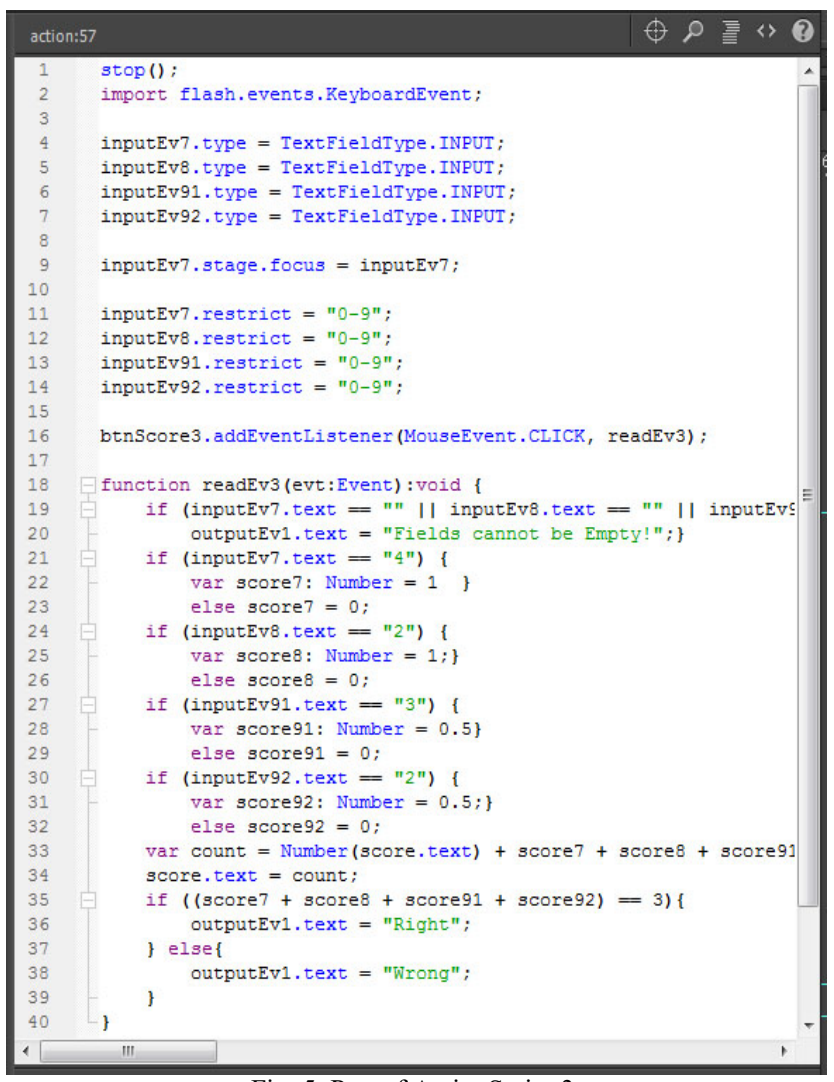

Fig. 5. Part of ActionScript 3.

\section{Preliminay Testing}

Fig. 3 shows the product display that was evaluated by peers who had have sufficient competence in the field of education, visual communication design, and information technology conducted during the production process was almost complete. Based on the evaluation of peers, the researcher should have made improvements as follows: (1) The mathematics mobile game was less communicative, because there was no clear instructions what to do. To overcome this, it should be created a text that explains each instruction; (2) Fonts that were used to explain the subject being studied was too small and lacking in contrast, and (3) One of the evaluators stated that the button was not interesting for children, it should be changed with drawing symbol.

After the product was completed, the next step was the evaluation by three expertise, who experted in education, visual communication, and information technology. Education expertise said that it should be include mix 
operations in practice and testing. Visual communication expertise said that the display on screen is not interesting, and should be provided with more images and animations. Software engineering expertise said that the icons that were used should be familiar for users because they use to interact them with the mobile device.

\section{E. Preliminary Product Revision}

Based on the comments and suggestions from the education, visual communications, and information technology expertises, researcher make improvement as follows: (1) the learning material on mathematics were completed with mix operation in practice and evaluation; (2) The screen display was changed in appropriate advice, the color of text explanation of game was changed to be more contrast, the background color was changed to be lighter, and the icons were changed to be interesting; and (3) The font size was changed to be larger.

\section{STORE LISTING}

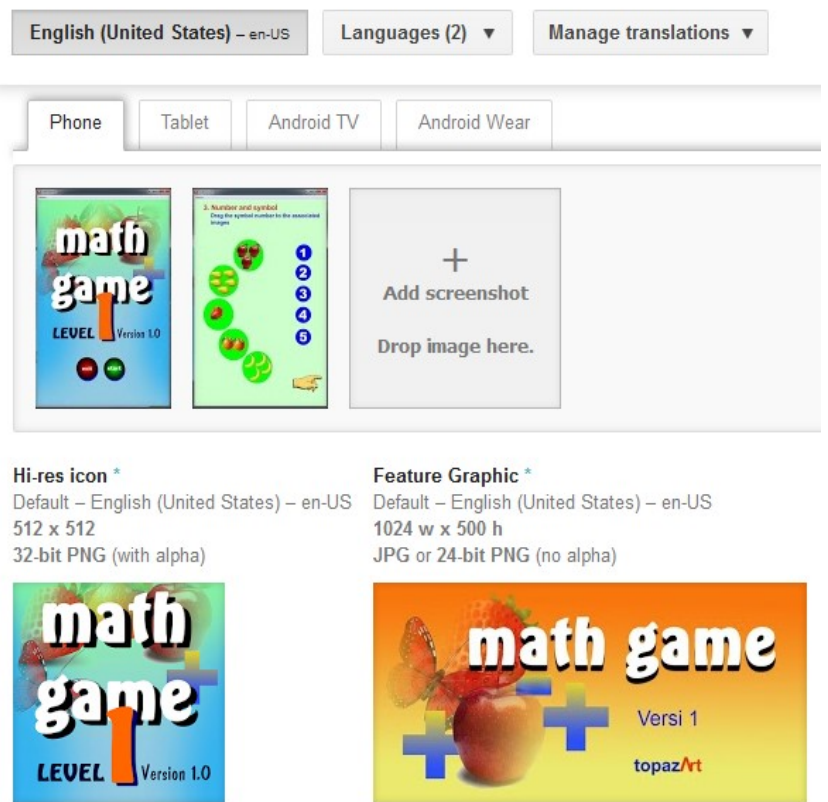

Fig. 6. Mobile game can be downloaded at Google Play Store.

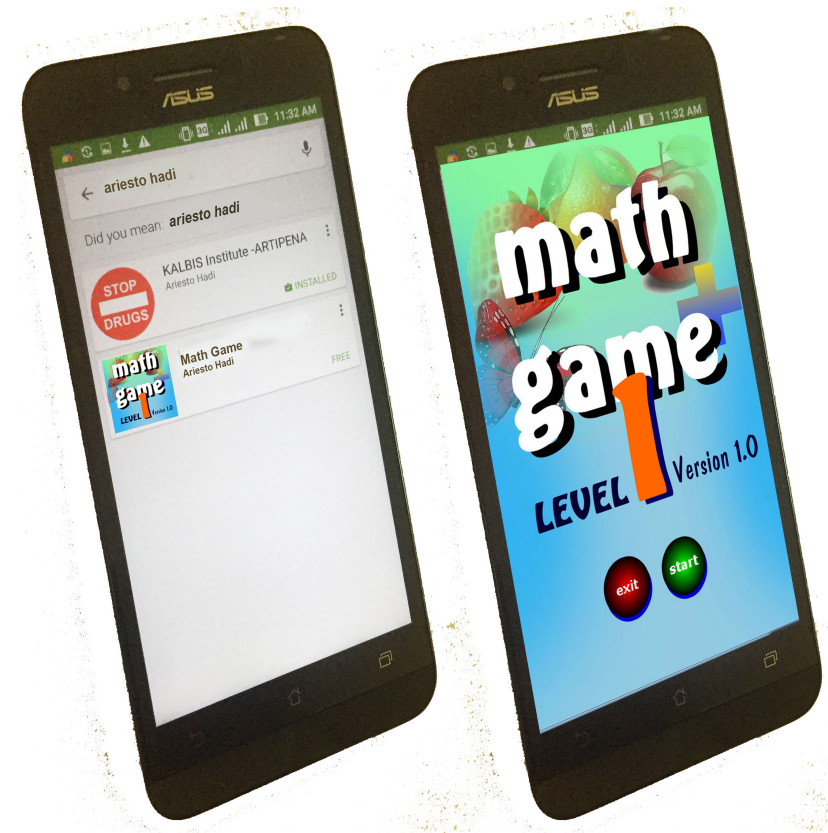

Fig. 7. Mobile game can be downloaded at Google Play Store.
After the mobile game had been revised, the next acitivity was uploading APK format file of mathemathics game to Google Play Store as can be seen in Fig. 6. Children, parents and teachers could download it into their smart phones as can be seen in Fig. 7, and they tried to play the game.

\section{F. Main Field Testing}

Main field testing was conducted in the elementary school in Jakarta Indonesia, involving 32 children of first grade and 4 teachers. The mathematics mobile game was downloaded by children's parents, and then the children played the game. Children evaluated the learning material whether the commands in the tutorial could be understood. Children said that learning material was considered complete to the simple game, and easy to understand. In general, children could solve the quiz in the game. Some of them said that they could not be able to do all the quiz at first, because they did not like mathematics. They liked the game because there were many interesting pictures, they played more than once, and they were very happy to succeed solving the problem in the game.

Advice was also given by parents to improve the product to be easily understood and used. According to parents, almost all of them agree that their children liked playing the game no matter they liked mathematics or not. Some of their children could solve the quiz on the game without parent's help and they said that the game was very useful.

According to the teachers, the learning objective could be shown in the tutorial was complete and easy to be learned. Teachers recommended that the tutorial would be interesting if it was provided numbers 1 to 20 . They argued that the mobile game could enhance student's learning motivation. The important thing was mixing addition and substraction. An error was found in the last text field, if user did not input number to the input fields then pressed the button, a test "Wrong" appeared in the output text, it should be "Fields cannot be Empty".

Research findings show that $11.1 \%$ of the respondents said that the mobile game was very good and proper to be played by children, $83.3 \%$ said that it was good, and $5.6 \%$ acceptable. None of respondents stated that it was poor or very poor, as can be seen in Fig. 8. The findings proofed that mathematics mobile game was suitable for use by children to improve his/her mathematics learning.

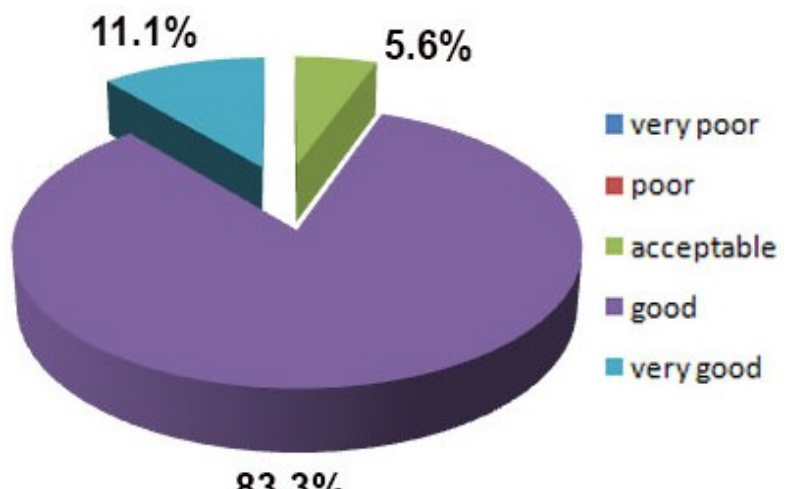

$83.3 \%$

Fig. 8. Chart of research findings.

\section{G. Operational Product Revision}

Based on the comments and suggestions in the main field testing, researcher made improvements as follows: (1) The 
game used the range number from 1 to 20; (2) The problem in evaluation is added with mixed aperations; and (3) Researcher revised some program in order fix the error output that was noted by teachers. The error output text was fixed as can be seen in Fig. 9.
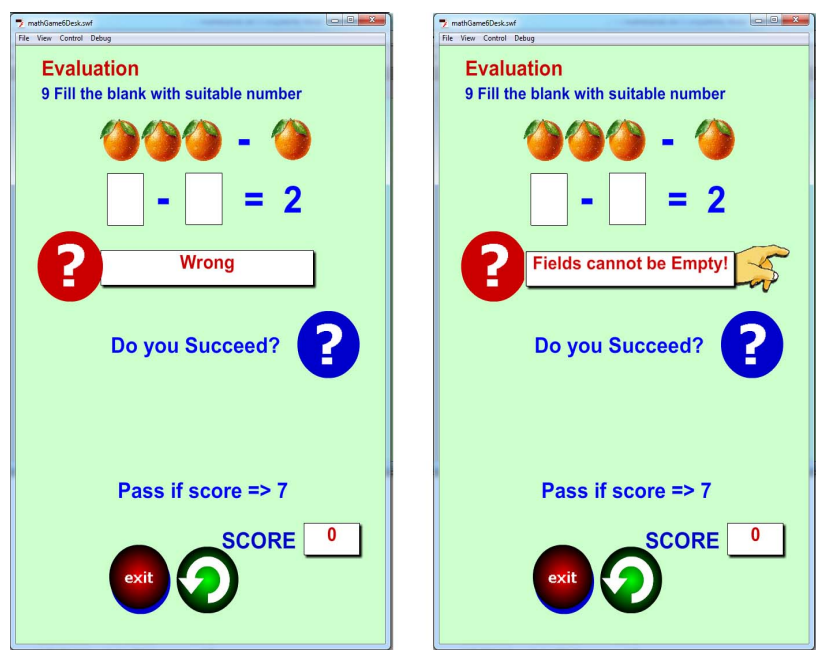

Fig. 9. Output text before (left) and after revision (right).

\section{H. Research Limitation}

Limitations of research in model development application especially mathematics mobile game includes three things: (1) The research and development included 10 stages were not fully implemented. The eighth stage Operational Testing, the ninth stage Final Product Revision, and the tenth stage Dissemination and Implementation were not conducted. This study was limited only from first stage to seventh, in accordance with the needs of the learning in Elementary School "X"; (2) The mathematics mobile game was especially intended for users who used smart phones with Android operating system and support Android 4 or above.

\section{CONCLUSION}

Based on the objectives and the results obtained in this study, it can be concluded as follows: (1) Initial research conducted at an elementary school to get the information needs to make a mathematics mobile game. Information is used as a guideline for developing multimedia application especially mathematics mobile game; (2) Development of multimedia applications especially mathematics game development learning model uses Borg \& Gall Research and Development Method and Multimedia Development Life Cycles according to Luther; (3) Most of children can solve the problem on mathematics mobile game; and (4) This mathematics mobile game is very useful to support learning, it can be used for self-learning and provide motivation in mathematics learning.

The computer game is created in an attempt to support the mathematics teaching, a subject that is often regarded as complicated by children of all ages. For future work, the mathematics mobile game needs to be developed for all grades of children. And, the mobile game should be able to run on IOs operating system, any kind of mobile device product, and resolution and orientation of mobile device.

\section{REFERENCES}

[1] C. Semiawan, Landasan Pembelajaran Dalam Perkembangan Manusia, Jakarta: CHCD, 2007, pp. 1-2.

[2] A. Arumsari et al., Pelajaran Matematika Untuk SD/MI Kelas 3, Bandung: CV Irama Widya, 2009, pp. 2.

[3] T. Vaughan, Multimedia Making it Work. Yogyakarta: Andi Publishers, 2006, pp. 1.

[4] Q. H. Mahmoud and A. Dyer, "Integrating blackberry wireless devices into computer programming and literacy courses," in Proc. of the 45th Annual Southeast Regional Conference (ACM-SE 2007), Winston-Salem, NC, USA, pp. 495-500, 2007.

[5] C. M. Reigeluth, "Instructional design: What is it and why is it," in C.M. Reigeluth, Design's Instructional Theories and Models, vol. I. New Jersey: Lawrence Erlbaum Association, 1999, pp. 15, 148-149.

[6] A. Katmada et al., (2014). Implementing a game for supporting learning in mathematics. The Electronic Journal of e-Learning. [Online]. 12(3). 230-242. Available: http://www.ejel.org/main.html

[7] W. R. Borg and M. D. Gall, Educational Research, New York: Longman, 2006, pp. 783-785.

[8] J. W. Creswell, Educational Research, Upper Saddle River, NJ: Pearson, 2008, pp. 224-225.

[9] A. C. Luther, Authoring Interactive Multimedia, Boston: AP Professional, 1994, pp. 19-25.

[10] D. Hearn and P. Baker, Computer Graphics C Version, 2nd ed. Upper Saddle River NJ: Prentice Hall International, Inc., 1996, pp. 25-33.

[11] D. Ypenburg, ActionScript 3.0: Learn ActionScript the Quick and Easy Way!, Berkeley, CA: Peachpit Press, 2009, pp. xiii-xiv.

[12] D. Sihombing, Tipografi dalam Desain Grafis, Jakarta: Gramedia Pustaka Utama, 2002, pp. 38-40.

[13] D. Franklin and J. Makar, Macromedia Flash MX ActionScripting Advanced Training from the Source, 2002, Berkeley, CA: Macromedia Press, pp.1.

[14] J. Mohler. Flash 5: Graphics, Animation, and Interactivity, Albany, NY: Onword Press, 2001, pp. 505.

[15] A. H. Sutopo, Multimedia Interaktif dengan Flash, Yogyakarta: Graha Ilmu, 2012, pp. 151-156.

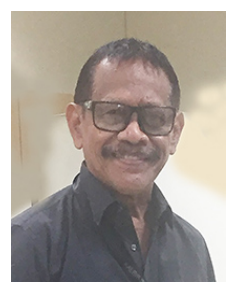

Hadi Sutopo was born in Cilacap, Indonesia on April 15, 1945. He is doctor of education in educational technology at the State University of Jakarta, graduated in November 2009. In 1998 he earned master of information systems at Post Graduate Program Gunadarma University, Jakarta. In 1995 he graduated from the Universitas Persada Indonesia YAI. Jakarta, majoring informatics.

Hadi is currently a lecturer of multimedia at Institut Teknologi dan Bisnis Kalbis and some other universities in Jakarta, Indonesia since 1998. He has been a trainer of multimedia based information systems and educational systems in many schools, universities, and organizations. He wrote many books on multimedia and information technology. Some of the books were Pemrograman Berorientasi Objek dengan Java (Yogyakarta, Indonesia: Graha Ilmu, 1995), Desain Buku dengan Adobe InDesign (Jakarta, Indonesia: Elex Media Komputindo, 2006), and Pemrograman Flash dengan PHP dan MySQL (Yogyakarta, Indonesia: Graha Ilmu, 2007). He has been a reviewer of Journal of Information System Education (JISE) since 2011.

He developed multimedia based mobile application and the latest were "Stop Narkoba" and "Math game" that can be download at Google Play Store. Current interest research is information technology especially multimedia.

Dr. Hadi Sutopo, MMSI is a senior member of International Association of Computer Science and Information Technology (IACSIT), member of Institute of Electrical and Electronics Engineers (IEEE), member of Association of Education and Communication Technology (AECT), and member of Indonesian Association of Educational Technology (IPTPI). 